\title{
THE IMPORTANCE OF THE VETERINARY MEDICAL IN THE INTEGRATED PREVENTIVE MONITORING
}

José Andreey Almeida TELES ${ }^{\mathbf{1}}$; Isaac Manoel Barros de ALBUQUERQUE²; Thiago Augusto Pereira de MORAES ${ }^{3}$; Francisco Feliciano da SILVA JÚNIOR ${ }^{4}$; Wellington Diniz Machado FILHO $^{5}$; Gil Dutra FURTADO ${ }^{6}$; Aleudson dos Santos SILVA ${ }^{7}$

${ }^{1}$ Graduate in Veterinary Medicine/Universidade Federal de Campina Grande (UFCG); Specialist in Infectiouscontagious Diseases of Domestic Animals/Universidade Federal Rural of Pernambuco (UFRPE); Master in Animal Bioscience (UFRPE); Doctor in Veterinary Science (UFRPE), Brazil. E-mail: teles.jaa@ gmail.com

${ }^{2}$ Graduate in Veterinary Medicine /Universidade José do Rosário Vellano (Unifenas); Specialist in Clinic and Surgery of Wild Animals by the Universidade Tuiuti of Paraná; Master of Science in Universidade of São Paulo (USP), Brazil. E-mail: isaacalbuquerque@ hotmail.com

${ }^{3}$ Graduate in Veterinary Medicine/Universidade Federal Rural of Pernambuco (UFRPE); Master in Veterinary Science /UFRPE; Doctorate in Animal Bioscience/UFRPE. President of the Regional Council of Veterinary Medicine of the state of Alagoas (CRMV-AL); Veterinarian of the Municipal Health Department of Maceió, Brazil. E-mail: thiagomoraes2001@bol.com.br

${ }^{4}$ Graduate in Veterinary Medicine /Universidade Federal Rural of Pernambuco (UFRPE); Specialist in Ruminantes Medical Clinic/Universidade Estadual Paulista Júlio de Mesquita Filho (UNESP); Master in Veterinary Preventive Medicine and Public Health/Universidade Estadual Paulista Júlio de Mesquita Filho (UNESP); Doctor of Preventive Veterinary Medicine and Public Health/Universidade Estadual Paulista Júlio de Mesquita Filho (UNESP), Brazil. E-mail: felicianojr@yahoo.com.br

${ }^{5}$ Graduate in Veterinary Medicine /Centro Universitário Cesmac, Brazil. E-mail: wellingtondiniz_vet@hotmail.com

${ }^{6}$ Student of the $2^{\text {nd }}$ period of the Veterinary Medicine Course of the Faculdade Maurício de Nassau; Agronomist Engineer/Universidade Federal da Paraíba (UFPB); Doctor of Psychobiology/Universidade Federal do Rio Grande do Norte (UFRN); Agronomist-Partner of the Agribusiness Cooperative (COOPAGRO), Brazil. E-mail: gdfurtado@hotmail.com

${ }^{7}$ Student of the $2^{\text {nd }}$ period of the Veterinary Medicine Course of the Faculdade Maurício de Nassau, Brazil. Email: aleudson@gmail.com

Abstract. The Integrated Preventive Monitoring began in 2002 with the initiative of the Public Ministry of the State of Bahia, and the Hydrographic Basin Committee of the São Francisco River. In Alagoas the Defense Center of Environment Public Ministry of the State coordinates the same. The representation of the Veterinarian in Integrated Preventive Surveillance is responsible for the activities in slaughterhouses and dairy, wild fauna and ichthyofauna, and in the fight against the irregular disposal of residues of dangerous products. The objective of this study was to demonstrate the importance of the veterinary professional in the FPI actions of the São Francisco River Basin. The 
work has resulted in the improvement of the well-being of the riverside population of the São Francisco River and, consequently, it has minimized the environmental impacts caused by the socioeconomic disruption of the region of the referred Basin.

Keywords: Slaughterhouse; Dairy; Wildlife; Fish populations.

\section{A IMPORTÂNCIA DO MÉDICO VETERINÁRIO NA FISCALIZAÇÃO PREVENTIVA INTEGRADA}

Resumo. A Fiscalização Preventiva Integrada (FPI) teve início em 2002, com a iniciativa do Ministério Público do Estado da Bahia, e do Comitê da Bacia Hidrográfica do Rio São Francisco. Em Alagoas, a mesma é coordenada pelo Núcleo de Defesa do Meio Ambiente do Ministério Público do Estado. A representação do Médico Veterinário na Fiscalização Preventiva Integrada compete às atuações em matadouros e laticínios, fauna silvestre e ictiofauna, e no combate ao descarte irregular de resíduos de produtos perigosos. Objetivou-se demonstrar a importância do profissional médico veterinário nas ações da FPI da Bacia Hidrográfica do Rio São Francisco. O trabalho vem resultando na melhoria do bem-estar da população ribeirinha do Rio São Francisco e, por consequência, tem minimizado os impactos ambientais causados pela desestruturação socioeconômica da região da referida Bacia Hidrográfica.

Palavras-chave: Matadouro; Laticínio; Fauna Silvestre; Ictiofauna.

\section{LA IMPORTANCIA DEL MÉDICO VETERINARIO EN LA FISCALIZACIÓN PREVENTIVA INTEGRADA}

Resumen. La Fiscalización Preventiva Integrada (FPI) comenzó en 2002, con la iniciativa del Ministerio Público del Estado de Bahía, y del Comité de la Cuenca Hidrográfica del Río São Francisco. En Alagoas, la misma es coordinada por el Núcleo de Defensa del Medio Ambiente del Ministerio Público del Estado. La representación del Médico Veterinario en la Fiscalización Preventiva Integrada corresponde a las actuaciones en mataderos y lácteos, fauna silvestre e ictiofauna, y en el combate al descarte irregular de residuos de productos peligrosos. Se objetivó demostrar la importancia del profesional médico veterinario en las acciones de la FPI de la Cuenca Hidrográfica del Río São Francisco. El trabajo viene resultando en la mejora del bienestar de la población ribereña del Río São Francisco y, por consiguiente, ha minimizado los impactos ambientales causados por la desestructuración socioeconómica de la región de la referida Cuenca Hidrográfica.

Palabras clave: Matadero; Productos lácteos; Fauna Silvestre; Poblaciones de peces.

\section{INTRODUCTION}

The São Francisco River, and its tributaries, form the São Francisco River Basin (VELHO CHICO, 2014). The São Francisco River Basin is the third largest in the Brazilian territory 
and the only one in Brazil, covering six states: Minas Gerais, Goiás, Bahia, Alagoas and Sergipe, as well as the Federal District, covering an amount of 504 municipalities (BRASIL, 2012; CBHSF, 2016).

Popularly known as "Velho Chico", the São Francisco River is born in the Serra da Canastra, in Minas Gerais, in the city of São Roque das Minas, and until reaching the mouth, travels about 2,800 km long, ending at the Atlantic Ocean (SUÇUARANA, 2016).

Throughout its extension, the São Francisco River brings life and hope to the people that were becoming, making possible the creation of traditional and peculiar ways of living of this region. Besides being a barn for the existence of several species of fauna and flora, many of them endemic and threatened with extinction, Velho Chico provides a scenario of exuberant natural beauties (VELHO CHICO, 2014).

Due to the potential of its waters, the São Francisco River and its tributaries allowed the development of several economic activities throughout its territory. For a long time, the irrational use of water resources and the development of activities disrespecting environmental norms have caused a scenario of great ecological and social problems in this basin, being such damages caused by several vectors of degradation. In order to face the challenge of changing this situation, the state and federal public agencies of the environment and health, public ministries and police, began to carry out Integrated Preventive Inspection in the São Francisco River Basin ("Fiscalização Preventiva Integrada na Bacia do Rio São Francisco"-FPI) (VELHO CHICO, 2014).

The FPI is an initiative of the Public Ministry of the State of Bahia ("Ministério Público do Estado da Bahia"-MPBA) and the São Francisco River Basin Committee ("Comitê da Bacia Hidrográfica do Rio São Francisco"-CBHSF). Held since 2002, FPI has already expanded to the Paraguassu River Basin and to the State of Alagoas (CRMV-BA, 2016).

In Alagoas, FPI is coordinated by the Nucleus of Defense of the Environment of the Public Ministry of the State of Alagoas ("Núcleo de Defesa do Meio Ambiente do Ministério Público do Estado de Alagoas"-NDEMA/MPAL). It is composed of 24 federal and state administrative organs, aiming to diagnose environmental damage in municipalities dependent on the São Francisco River and to adopt preventive measures, repressing violations of all kinds, aiming at the welfare, improving the quality of life of the populations of the region and safeguarding them from risk situations (CPAL, 2016).

Therefore, even if these inspections, educational and preventive, noncompliance with the requirements, as a result of the inspections, can result in the issuance of infraction notices, in the partial prohibition, or in the most serious cases. Even in the request of total prohibition 
of the establishment and equipment, through judicial measures, according to legislation pertaining to each body (CPAL, 2016; CREA-RN, 2016).

In view of the actions of the FPI in the socio-environmental, public health, wildlife preservation and conservation areas, the objective is to demonstrate the importance of the veterinary medical professional in the actions of the Integrated Preventive Inspection of the São Francisco River Basin.

\section{Veterinary Physician Attributions at FPI}

The diversity of bodies involved in FPI is intended to contemplate actions in various sectors of society, covering topics such as water quality, waste disposal, disposal of agrochemicals packaging, sewage treatment, extraction of products of plant origin, implantation and operation of charcoal, historical patrimony, health and food, and wild animal breeding (CREA-RN, 2016; CRMV-BA, 2016).

With regard to the participation of the veterinarian, the veterinarian is represented in more than one FPI team, interacting with other professionals, aiming to promote the health integrity and quality of food, to which we can highlight the supervision in slaughterhouses and dairy products (VELHO CHICO, 2014).

In the planning of FPI actions, a team is delegated to work in slaughterhouses and dairies to combat and/or minimize the environmental impacts caused by these establishments, such as the physical, chemical and biological properties of the environment, caused by human activities that directly or indirectly affect the health, safety and well-being of the population, social and economic activities, biota, sanitary conditions, and the quality of natural resources (CONAMA, 1986).

Among the FPI's targets, we highlight fish fauna, fauna, commercialization of dangerous products, maintenance and exhibition of animals for sale and registration of establishments that carry out activities related to veterinary medicine (VELHO CHICO, 2014).

As regards wildlife, the program investigates the illegal creation of wild animals, with animal trafficking being the most serious offense. The illegal trade in animals and unbridled hunting is one of the main causes of the extermination of species from the wildlife (HERNANDEZ; CARVALHO, 2006).

Already the team inspecting irregular occupations and marketing of dangerous products promotes the minimization of risks to public health by fighting and control of waste 
conveyed by water and food, as well as the embargo and ban on construction in areas of permanent protection and protection (ANVISA, 2009).

The indiscriminate use of chemicals in agricultural areas poses a threat to the environment (MATTOS; SILVA, 1999). Water resources act as integrators of the biogeochemical processes of any region. Therefore, pesticides tend to be destined to water resources, whether surface or underground (FERRAZ, 1996).

\section{Irregular Occupation and Commercialization of Hazardous Products}

The team responsible for these demands inspects urban and rural properties, observing the buildings in Areas of Permanent Preservation (APP), as well as the legal reserve of these properties, the use of pesticides, regularity in the water catchment, the presence of technical personnel, deforestation, existence of industries, dams, among other ventures (VELHO CHICO, 2014).

\section{Irregular Occupation}

The environmental balance of drained areas by river basins has been affected by the consequences of deforestation on water resources, affecting the quality of life of the riverine population. As the demand for its various uses (supply, irrigation, energy generation, livestock, among others) increases, the actions directed to promote changes in the predatory form of its use continue to be implemented in a very limited way, although these resources recognized by the different segments of society, of paramount importance for the survival of mankind (NASCIMENTO, 2005).

Another concern is the installation and operation of charcoal. The agreements signed between the charcoal properties and the competent bodies would be to suppress vegetation for the use of the soil in agriculture or pasture with the use of the woody material, but in practice, the properties only suppress the vegetation without the reuse of the deforested areas, practice prohibited by Law 12.651, of May 25, 2012 (VELHO CHICO, 2014).

In order to preserve the forests and other forms of vegetation in Brazilian territory, the Forest Code (Law 4.771/65) instituted APPs, in which native vegetation must be maintained in its integrity, and any economic exploitation is prohibited.

Provisional Measure No. 2,166-67/01, which added paragraph II, paragraph 2, to Art. 1 of Federal Law 4,771/65, defines APPs as protected areas in terms of Arts. 2 and 3 of this law, covered or not by native vegetation, with the environmental function of preserving water resources, landscape, geological stability, biodiversity and the gene flow of flora and fauna; 
protect the soil; and to ensure the well-being of human populations, and to act as a sink for erosive energy.

In general, the preservation and conservation of native vegetation, especially that situated along watercourses, springs and rugged topography regions, has a great importance for the protection of water resources (BRASIL, 1965; JACOVINE, 2008).

\section{Marketing of Hazardous Products}

The indiscriminate use of agrochemicals poses a threat to the environment, especially water and food. The consequent contamination by pesticide residues has been a constant concern in the field of public health. Several levels of government have invested and implemented programs of action and control of residues that can eliminate or mitigate the health risks of Brazilians regarding the presence of residues in water and food (ANVISA, 2009; MATTOS; SILVA, 1999).

Considering that the climatic conditions of the São Francisco River are favorable to the appearance of pests and diseases, the use of pesticides is inevitable to ensure agricultural production. These, in turn, compromise water and soil quality (FERRAZ, 1996).

In Brazil, Aldicarb, known as "chumbinho", specifically, is a systemic insecticide that must be mixed with the soil, but has been misused as rodenticide. It is considered the most potent carbamate on the market and is classified by the Environmental Protection Agency (EPA), the United States Environmental Protection Agency, in the highest category of toxicity, being of restricted use (MARTINS, 2005).

However, besides the illegal sale, the product has been adulterated, adding graphite, milled corn, wheat flour, canary seed, sand, among other products. The various episodes of intoxication, due to different types of exposure, occur due to the ease of acquisition of the product in the informal market, considering the severity of the indiscriminate use of this product and, above all, the relevance of the subject to public health (MARTINS, 2005) .

The concentration of pesticides in water tends to be low, partly because they are poorly soluble and partly because of the dilution effect. However, even at these concentrations, such products present risks to some species of aquatic organisms, which can concentrate them up to 1000 times (FERREIRA, 2001).

\section{Slaughterhouse}

Slaughterhouses are establishments equipped with complete facilities and adequate equipment for the slaughter, handling, preparation and conservation of the species (ROÇA, 2010). The 
quality of the meat is characterized by its physicochemical properties, translated, in the evaluation of who consumes it, in softness, flavor, color, aroma and juiciness. These properties are determined by many factors inherent to the individual (genetics, age, sex), the unit of origin of origin (food handling, general management), transportation, pre-slaughter handling, slaughter and carcass processing methods, to the duration and temperature of storage and the form of cooking used (COSTA et al., 2006).

The consumer, with each passing day, has a greater concern regarding the quality of the products, just as companies act in the preservation of the environment (ROCHA, 2006; SILVA, 2012). In this context are the humanitarian slaughter and correct disposal of waste.

In Alagoas, humanitarian slaughter and waste disposal are aspects to be inspected by the FPI, thus, only the veterinary medical professionals of the Agricultural Defense Agency of Alagoas (“Agência de Defesa e Inspeção Agropecuária de Alagoas"-ADEAL) and the Regional Council of Veterinary Medicine of Alagoas ("Conselho Regional de Medicina Veterinária de Alagoas"-CRMV/AL) have the technical competence to act in these contexts.

\section{Humanitarian Abatement}

The technology of the slaughter of animals destined for consumption only assumed scientific importance when it was observed that the events that happen from the rural property to the slaughter of the animal exert a great influence on the quality of the meat (SWATLAND, 2000).

According to Normative Instruction 17, No. 3 of January 17, 2000, the Ministry of Agriculture, Livestock and Supply ("Ministério da Agricultura, Pecuária e Abastecimento"MAPA) (BRASIL, 2000), humanitarian slaughter is defined as a set of technical and scientific guidelines that guarantee the well- being from the reception to the sangria.

Animal welfare is defined in a profile of five freedoms that must be met: psychological freedom (of not feeling fear, anxiety or stress); behavioral (to express their normal behavior); physiological (not feeling hungry or thirsty); health (not being exposed to illness, injury or pain); and environmental (to live in adequate environments, with comfort) (FAWC, 2009; NAAS, 2008; TRECENTI, 2013).

In the inspection of the IPF in slaughterhouses, specifically, the veterinarian is involved in the inspection, from the reception of the animals, through pre-slaughter management, to how animals are being slaughtered, following the rules of animal welfare and, finally put up for transport. 


\section{Disposal of Waste}

The retrograde way of thinking that the environment is a container of waste and waste of production and consumption, it is no longer the responsibility of the one who is aware that this environment also has its limits (BARBIERI, 2004).

The concept of waste appears through time, of population evolution, where the first environmental imbalances promoted by humans appeared, characterized both by the physical changes and the intensity of the extractions in the natural environment, as well as by the "remains" left as a result of their survival and of their "development" (FIGUEIREDO, 1995).

The real need for protein means that the population does not change their eating habits, so the recycling of animal remains is a solution to minimize the waste disposal. The accumulation of organic matter that is easily putrescible, such as by-products of slaughter, in places like slaughterhouses, meat houses, butchers or supermarkets implies the increase of the levels of risks of several orders, as labor, environmental, and public health (BARROS; LICCO, 2004).

In this sense, the rational use of meat by-products and residues, besides being economically important in the meat cost matrix, is extremely relevant as regards the labor, environmental and public health aspects, because if they were not used, they would be transformed into pollutants of difficult treatment and in outbreaks of disease spread (BARROS; LICCO, 2004).

In the Integrated Preventive Surveillance, from the technical point of view of the veterinarian, the aspects regarding the behavior and the equipment of individual protection of the employees when carrying out the activities in the slaughterhouses, as the slaughter byproducts are being discarded, and the risks of cross-contamination between discard products and those intended for slaughtering food consumption.

\section{Dairy}

The dairy industry processes various dairy products in a variety of ways. These activities are well-publicized in all Brazilian regions, contributing a portion of great relevance in the food industry. As a result, this activity constantly releases liquid effluents into the environment (SARAIVA, 2008).

Milk, as well as other foods of animal origin, from the process to the commercialization can be contaminated by pathogenic microorganisms or even by toxic substances that imply risks to human health (SANTOS, 2001). 
The wastewater from the dairy industry includes liquids from industrial processes, sanitary sewers and rainwater. By-products such as whey and buttermilk, even when used, will contribute to the composition of wastewater (SARAIVA, 2001).

The dairy industry is under surveillance by FPI Alagoas, where, at the time, ADEAL and CRMV/AL veterinarians have technical qualification to inspect these establishments.

\section{Fauna}

The fauna is defined as a set of all terrestrial and aquatic animals, including microorganisms, living in an area (region or country) in their different categories in relation to their habitat and the respective conditions of existence (HERNANDEZ; CARVALHO, 2006).

Initially, the term was defined in article 1 of Law 5,197/67 and modified by paragraph 3 of art. 29 of Law 9,605/98, which covers all native, migratory and any other species, aquatic or terrestrial, that have all or part of their life cycle occurring within Brazilian territory or waters. There is also Decree-Law no. 221/67 dealing with aquatic fauna (marine and freshwater), conceptualizing it as having the natural habitat or more frequent means of life in water.

This doctrinal conception of wild animal goes against the Federal Constitution, whose art. 225, paragraph 1, inc. VII, affirms that "the fauna and flora must be protected, protected by law, practices that jeopardize their ecological function, cause extinction of species or subject animals to cruelty."

The fauna, as one of the most important surveillance targets in the Alagoas FPI Program, precisely because it ensures a certain balance of the specimens and animal species in the region, has the veterinarian as a professional capable of clinical diagnosis and reintroduction of animals captured in captivity (legalized or not), which will depend on the conditions in which the animals are found and reinserted in their habitat.

\section{Ichthyofauna (Fish Fauna)}

Fish farming in the São Francisco Basin is intense, leading the region to become the most important pole in Brazilian fish farming, due to the social and economic appeal of the activity, especially in areas where there is a breeding ground in tanks with high technology and productivity (BARBOSA; SOARES, 2009).

However, the river bus, with the purpose of generating electric power, aggravated a conflict over the use of resources, making it difficult to maintain natural stocks throughout the basin. The impacts generated on the reproductive migration of fish, alteration of the lotic to 
the lentic system and modification of the structure of aquatic communities, triggered a series of interventions in the behavior and composition of the ichthyofauna, when some species of the Basin collapsed (FRID et al., 2000).

Despite the impact caused by anthropogenic actions in the São Francisco Basin, some areas still have stocks and intense fishing activity. It is worth mentioning that many allochthonous species have already been introduced in the São Francisco Basin, when their reservoirs have been settled (ALVES et al., 2007).

Many fish genera found in the São Francisco basin are common to the Amazon, Parnaíba and Paraná-Uruguay basins. However, there is greater ichthyofaunistic similarity between the São Francisco river and the Pardo / Mogi-Guaçu rivers (Paraná-Uruguay Basin), than between the Paraná River and the Parnaíba River (Maranhão/Piauí) (BARBOSA, 1986).

The ichthyofauna of São Francisco presents a high degree of endemism, especially in annual fish. An example is Salminus brasiliensis described as S. franciscanus, a new species endemic in the basin (LIMA; BRITSKI, 2007).

Despite the importance and tradition of the São Francisco Basin, fishing and fishermen have been suffering from socio-environmental problems over time (VELHO CHICO, 2014). Hence the relevant role of the veterinarian in improving technologies for improving fish production and technical assistance in the development of new intensive breeding methods.

\section{Wildlife}

This is one of the natural resources that has become a victim of human greed because they adopt wild animals as pets (ZAGO, 2008).

The custom of using wild animals in food or as pets is a historical process. This habit still persists, compromising the conservation of the species, as it contributes to the trafficking of native fauna (BORGES et al., 2006). Even after Law No. 5,197/67 (Law on Protection of Fauna), and later Law 9,605/98 (Law on Environmental Crimes), criminalizing the misuse of fauna, the problem persists on a large scale, with some regional differences the type of use.

The fight against the illicit use of wild fauna is the responsibility of the competent state organs. This activity moves annually, in Brazil alone, approximately 2.5 billion dollars (RENCTAS, 2001).

Seized wildlife are usually intended for zoos, Wildlife Screening Centers ("Centro de Triagem para Animais Silvestres"-CETAS) or conservationist and scientific breeding sites. However, in spite of the fact that the responsibility for adequate allocation falls on public 
power, in some Brazilian states this task has been assumed by private institutions (SOORAE; PRICE, 1999).

According to Art. 29 of the Environmental Crimes Law, it is considered a crime, to kill, to persecute, to hunt, to catch, to use wildlife specimens, natives or on a migratory route, without the proper permission, license or legal authorization (BRASIL, 1998).

Based on this article, we conceptualize that the veterinarian, biologists and official environmental inspection and defense agencies play an extremely important role in combating animal trafficking, in the maintenance of animals seized in captivity, until their reintroduction into the and from the absence of freedom, to the lack of food necessary for the maintenance of the life of the species. The average citizen is not allowed to acquire or capture wild animals from nature to be keep as pets.

\section{CONCLUSIONS}

In view of the diversity of actions related to the range of veterinary medical professional performance, as well as the specificities inherent to certain commercial activities developed in all the municipalities visited since the first stage of the FPI, it is possible to affirm that the presence of veterinarians in actions of this nature has a great importance.

Moreover, the performance of this professional in multidisciplinary teams always serves as a stimulus to the improvement, more precisely with respect to the improvement of actions and development of new forms of approaches in establishments that generate impacts directly or indirectly in the environment comprised both by the Velho Chico as well as its tributaries.

\section{REFERENCES}

ALVES C.B.M.; VIEIRA F.; MAGALHÃES A.L.; BRITO M.F.G. Impacts of non-native fish species in Minas Gerais, Brazil: present situation and prospects. In: BERT, T.M. (ed). Ecological and genetic implications of aquaculture activities. Dordrecht: Springer, 2007.

ANVISA (Agência Nacional de Vigilância Sanitária). Programa de Análise de Resíduos de Agrotóxicos em Alimentos - PARA. Brasília: Relatório de Atividades, 2009.

BARBIERI, J.C. Gestão Ambiental Empresarial: conceitos, modelos e instrumentos. São Paulo: Saraiva. 2004. 
BARBOSA, J.M. Semelhança faunística entre as bacias dos rios Moji-Guaçu, São Francisco e Parnaíba. In: V Sem. Reg. de Ecologia. 1986. São Carlos: SP. Anais do V Sem. Reg. de Ecologia. São Carlos, SP: UFSCar. 1986.

BARBOSA, J.M.; SOARES, E.C. Perfil da Ictiofauna da Bacia do São Francisco: Estudo Preliminar. Revista Brasileira de Engenharia de Pesca. n. 4. Ano. 2009.

BARBOSA FILHO, J.A.D.; SILVA, I.J.O. Abate humanitário: ponto fundamental do bemestar animal. Revista Nacional da Carne. São Paulo. n. 328. p.36-44, 2004.

BARROS, F.D.; LICCO, E.A. A Reciclagem De Resíduos De Origem Animal: Uma Questão Ambiental. Instituto Mauá: São Paulo. 2004. Disponível em: $<$ http://maua.br/files/artigos/a-reciclagem-de-residuos-de-origem-animal-uma-questaoambiental.pdf> Acesso em: 31 de out. 2016.

BORGES, R.C.; OLIVEIRA, A.; BERNARDO, N.; COSTA, R.M.M.C. Diagnóstico da fauna silvestre apreendida e recolhidos pela Polícia Militar de Meio Ambiente de Juiz de Fora, MG. Revista Brasileira de Zoociências. n.8. p. 23-33. 2006.

BRASIL. Lei no 9.605 de 12 de fevereiro de 1998. Lei dos Crimes Ambientais. Presidência da República Federativa do Brasil. Disponível em: <http://www.planalto.gov.br/ccivil/leis/L9605.htm>. Acesso em: 18 de out. 2016.

BRASIL. Ministério da Agricultura, Pecuária e Abastecimento. Instrução normativa no 3. 17/01/2000. Brasília, DF, 2000.

BRASIL. Lei Federal n. 4.771, de 15 de setembro de 1965. Institui o Novo Código Florestal Brasileiro. Brasília, DF, 2002.

BRASIL. Instituto Chico Mendes de Conservação da Biodiversidade. Plano de Ação Nacional Para a Conservação do Patrimônio Espeleológico nas Áreas Cársticas da Bacia do Rio São Francisco. Brasília, DF, 2012, p. 29. 
CBHSF, Comitê da Bacia Hidrográfica do Rio São Francisco. 2016. Disponível em: http://cbhsaofrancisco.org.br/bacia-hidrografica-do-rio-sao-francisco/caracteristicas-gerais. Acesso em: 26 set. 2016.

CONAMA (Conselho Nacional do Meio Ambiente). Resolução n. 01, de 23 de janeiro de 1986. Dispõe sobre critérios básicos e diretrizes gerais para a avaliação de impacto ambiental. Diário Oficial [da] República Federativa do Brasil, Poder Executivo, Brasília, DF, 17 de fev. 1986. Seção 1, p. 2548-2549.

COSTA, M.J.R.P.; CHIQUITELLI NETO, M.; LUCHIARI FILHO, A.; BARCELLOS, M.D. Racionalização do manejo de bovinos de corte: bases biológicas para o planejamento (ambiente de criação, instalações, manejo e qualidade da carne). ABNP. 2006. Disponível em: http://vetxerox.blogspot.com/2013/10/artigo-racionalizacao-do-manejode.html\#.XCiP3lVKjIU. Acesso em: 11 dez. 2016.

CPAL, Capitania dos Portos de Alagoas. 2016. Disponível em: https://www1.mar.mil.br/cpal/node/90. Acesso em: 16 ago. 2016.

CREA-RN, Conselho Regional de Engenharia e Agronomia do Rio Grande do Norte. 2016. Disponível em: http://www.crea-rn.org.br/fpi. Acesso em: 16 ago. 2016.

CRMV-BA, Conselho Regional de Medicina Veterinária da Bahia, 2016. Disponível em: http://www.crmvba.org.br/noticias.php?news_not_pk=907. Acesso em: 16 ago. 2016.

FAWC, Farm Animal Welfare Committe. Five Freedoms. United Kingdom. 2009.

FERRACINI, V.L.; PESSOA, M.C.Y.P.; SILVA, A.S.; SPADOTTO, C.A. Análise de Risco de Contaminação das Águas Subterrâneas e Superficiais da Região de Petrolina (PE) e Juazeiro (BA). Curitiba: Embrapa Meio Ambiente. 2001.

FERRAZ, E.S.B. A bacia hidrográfica como unidade de estudo, estrutura e processos (apresentação). In: WORKSHOP DO PROJETO PIRACENA, 2, Piracicaba, 1996. Anais... Piracicaba: CENA, 1996. p.7. 
FIGUEIREDO, P.J.M. A sociedade do lixo: os resíduos, a questão energética e a crise ambiental. 2.ed. São Paulo: Unimep. 1995.

FRID, C.L.J.; HARWOOD, K.G., HALL, S.J.; HALL, J.A. Long-term changes in the benthic communitie son North Sea fishing grounds. ICES Journal of Marine Science, n. 57.p.1303-1309, 2000.

HERNANDEZ, E.F.T.; CARVALHO, M.S. O tráfico de animais silvestres no Estado do Paraná. Acta Scientiarum. Human and Social Sciences, Maringá, v. 28, n. 2, p. 257-266, 2006.

JACOVINE, L.A.G.; CORRÊA, J.B.L.; SILVA, M.L.; VALVERDE, S.R.; FERNANDES FILHO, E.I.; COELHO, F.M.G.; PAIVA, H.N. Quantificação das Áreas de Preservação Permanente e Reserva Legal em Propriedades da Bacia do Rio Pomba - MG. v. 32. n. 2. Minas Gerais: UFV. 2008.

LIMA, F.C.T.; BRITSKI, H.A. Salminus franciscanus, a new species from the rio São Francisco basin, Brazil (Ostariophysi: Characiformes: Characidae). Neo tropical Ichthyology 5(3):237-244. 2007.

MARTINS, E.H.C. Intoxicação por Aldicarb no Estado da Bahia, Brasil. Revista Baiana de Saúde Pública. v. 29. p. 77-88, jan./jun. 2005.

MATTOS, L.M.; SILVA, E.F. Influência das propriedades de solos e de pesticidas no potencial de contaminação de solos e águas subterrâneas. Pesticidas: R. Ecotoxicol. e Meio Ambiente. Curitiba. v. 9. p. 103-124. jan./dez. 1999.

NAAS, I.A. Princípios de Bem-Estar Animal e Sua Aplicação na Cadeia Avícola. v.70. n.2. p.105-106. Campinas: São Paulo. 2008.

NASCIMENTO, M.C.; SOARES, V.P.; RIBEIRO, C.A.A.S.; SILVA, E. Uso do Geoprocessamento na Identificação de Conflitos de Uso da Terra em Áreas de Preservação Permanente na Bacia Hidrográfica do Rio Alegre, Espírito Santo. v. 15. n. 2. Santa Maria: Ciência Florestal. 2005. 
RAMOS, V.O.C. Pesca, pescadores e políticas públicas no Baixo São Francisco, Sergipe, Brasil. (Série meio ambiente em debate; 39). Brasília, Ed. IBAMA. 2001.

RENCTAS. Rede Nacional de Combate ao Tráfico de Animais Silvestres. $\mathbf{1}^{\mathbf{0}}$ Relatório Nacional sobre o Tráfico de Fauna Silvestre. 107p, 2001.

RIBEIRO, C.A.A.S.; V.P.SOARES; OLIVEIRA, A.M.S.; GLERIANI, J.M. O desafio da delimitação de áreas de preservação permanente. Revista Árvore. v. 29. n. 2. 2005.

ROCHA, M.P. Implantação de um sistema de gerenciamento de resíduos sólidos em uma fábrica de tintas. 2006. 90f. Dissertação (Mestrado em Engenharia de Produção) Universidade Federal de Santa Maria, Santa Maria/RS, 2006.

ROÇA, O.R. Abate de Bovinos. Laboratório de Tecnologia dos Produtos de Origem Animal. Fazenda Experimental Lageado. F.C.A: UNESP. Campus de Botucatu: São Paulo. 2010 .

SANTOS M.V.; LARANJA DA FONSECA L.F. Importância e efeito de bactérias psicotrópicas sobre a qualidade do leite. Revista Higiene Alimentar. v. 15. n. 82. p. 13-19. 2001.

SARAIVA, C.B. Potencial poluidor de um laticínio de pequeno porte: um estudo de caso. Viçosa. 2008. Disponível em: <http://www.tede.ufv.br/tedesimplificado/tde_arquiv os/39/TDE-2009-06-19T075605Z-1692/Publico/texto\%20completo.pdf> Acesso em: 18 de out. 2016.

SILVA, C.V.B.O. Abate Humanitário e o Bem-Estar Animal em Bovinos. Universidade Federal do Rio Grande do Sul. Faculdade de Veterinária. Porto Alegre. 2012.

SOORAE, P.S.; PRICE, M.R.S. Animales Confiscados Vivos: Qué Opciones Hay Para Su Ubicación? In: FANG, T.G.; MONTENEGRO, O.L.; BODMER, R. Manejo y conservación de fauna silvestre em America Latina. Editorial Instituto de Ecología. p. 63-68. La Paz. 1999. 
la.com/hidrografia/rio-sao-francisco/> Acesso em: 26 set. 2016.

SWATLAND, H.J. Slaughtering. Animal and Poultry Science. p.10. 2000.

TRECENTI, S.A. Abate Humanitário: Revisão de Literatura. Revista Científica Eletrônica de Medicina Veterinária. Ano XI. Garça: São Paulo. 2013.

VELHO CHICO: A Experiência da Fiscalização Preventiva Integrada na Bahia / Equipe FPI. $1^{a}$ Edição. Salvador: Ministério Público da Bahia e Órgãos Parceiros do Programa FPI. 2014.

ZAGO, D.C._Animais Da Fauna Silvestre Mantidos Como Animais De Estimação. Monografia de Especialização. Santa Maria: Rio Grande do Sul. 2008. 